УДК 330. 341.1

DOI: https://doi.org/10.37320/2415-3583/12.7

Вецепура Н.В.

кандидат економічних наук, доцент, доцент кафедри міжнародних відносин, Київський національний університет культури і мистещзтв

\title{
ІННОВАЦІЙНА СИСТЕМА УКРАЇНИ В УМОВАХ ГЛОБАЛІЗАЦІЙНИХ ПРОЦЕСІВ: СТАН ТА ПЕРСПЕКТИВИ РОЗВИТКУ
}

У статті викладено результати дослідження щчодо стану та перспектив розвитку інноваційної системи Украӥни в сучасних умовах. Зазначено, щчо низька активність промислових підприємств Украӥни у сфері створення та впровадження інновацій не дозволяє краӥні наблизитися до лідерів іннова-ціійного розвитку. Висвітлено причини, які привели до стагначії інноваційної моделі розвитку краӥни: низький технологічний рівень виробниитва, низька інновачійна активність підприємств реального сектору економіки, слабке державне фінансування інноваційних розробок, відсутність власних коштів на ведення інноваційної діяльності. Зроблено висновки щзодо актуальності досліджень у напрямі активізації інноваційної діяльності. У вивченні иієї проблеми ичентральне місие займає питання розвитку інноваційної інфраструктури.

Ключові слова: конкурентоспроможність, інновачійна діяльність, на-иіональна інновачійна система, стратегічне завдання, конкурентна перевага, ефективність, інновачійна інфраструктура.

Постановка проблеми. Сьогодні глобальна економіка знаходиться в умовах унікальних викликів, тобто ми вперше в історії спостерігаємо, як па-ндемія коронавірусу COVID-19 трагічно вплинула на економічну активність у всьому світі. Швидке відновлення економіки України та іiі зростання безу-мовно залежить від подолання пандемії та припинення обмежень, пов'язаних із іiі стримуванням, але не слід відвертати увагу від справжніх причин економічної кризи. Передусім кризу економіки України було спровоковано ще задовго до пандемії такими факторами, як: відсутність державної політики стимулювання розвитку національної економіки та зниження рівня конкурентоспроможності вітчизняних підприємств, зокрема в галузях 
iз вищою доданою вартістю, як на внутрішньому, так i на зовнішньому ринках.

Ситуацію, яка склалася, підтверджують і статистичні дані. Так, у IV кварталі 2019 року, та особливо в I кварталі 2020-го, було зафіксовано різке зменшення інвестицій у більшість галузей економіки України. У І кварталі 2020 року спостерігалося особливо сильне зниження капіталовкладень в індустріальній сфері: машинобудування $(-45 \%)$ та виробництво меблів $(-49 \%)$, легка промисловість $(-34,3 \%)$, деревообробна $(-33,8 \%)$, харчова $(-28,7 \%)$ і металургія $(-27,5 \%)$. Кризові тенденції в економіці України супроводжуються іiї рентоорієнтованою поведінкою. Так, спад в обробній промисловості значно перевищив аналогічні показники видобувної. Якщо останній спад на 6\% за результатами чотирьох місяців та $11,2 \%$ із початку року був спровокований насамперед зупинкою діяльності шахт, то в машинобудуванні виробництво продукції знизилося на $36,6 \%$ у квітні та на $19,7 \%$ із початку року, у легкій промисловості - на $37,8 \%$ та $13,6 \%$, у металургії - на $30 \%$ та 15,4\%, у деревообробці - на 23\% та 8,3\%. Серед великих галузей промисловості найкраще почувається харчова промисловість. Там виробництво знизилось у квітні лише на $6,5 \%$, а 3 початку року навіть зростало. Прогнозовано збільшилося в умовах пандемії і виробництво фармацевтичної продукції. Зберегло свої обсяги виробництво нафтопродуктів і хімічних виробів [1].

Враховуючи зазначене, швидке відновлення економіки України та по-дальше зростання неможливе без вироблення нової, інноваційно орієнтованої парадигми соціально-економічного розвитку нашої країни. Цей висновок підтверджується і зарубіжним досвідом. Тільки за одне десятиліття співвідношення факторів економічного зростання промислово розвинених країн зазнало значних змін: 1/4 приросту розвитку викликана прямими матеріальними вкладеннями капіталу, приблизно 1/3 - підвищенням кваліфікації робочої сили і більш 40\% економічного зростання цих країн результат використання новітніх наукових відкриттів, винаходів і досліджень, застосування технічних інновацій [2, с. 234].

Основні програмні заходи щодо розв'язання проблем побудови сучасної інноваційної економіки 3 розвинутим підприємництвом, інноваціями, високою продуктивністю виробництва та високим рівнем конкурентоспроможності галузей національного господарства Україні як держави відображені в «Стратегії інноваційного розвитку України на період до 2030 року». В стратегії, зокрема, говориться, що ii метою є розбудова національної інноваційної екосистеми для забезпечення підвищення рівня інноваційності національної економіки, що передбачає створення сприятливих умов для розвитку інноваційної сфери, та інноваційної діяльності. Однак з урахуванням викликів сучасності нині їх стан в Україні недостатній, що зумовлює необхідність виявлення на системній основі основних причин такого становища i визначення шляхів виходу з нього.

Аналіз останніх досліджень і публікацій. Дослідженню проблем розвитку інноваційної системи України присвячено багато наукових праць українських учених, таких, як О. Амоша [3], Г. Андрощук [4], В. Геєць
[5], О. П. Коюда [6], О. Харченко [7], Л. Федулова [8] та інші. Проте в умовах сучасних реалій багато питань, пов'язаних із розбудовою національної інноваційної екосистеми, які сприяють забезпеченню підвищення рівня інноваційності економіки України, залишаються ще недостатньо вирішеними, що свідчить про необхідність подальшого їх дослідження. Стан теоретичних і прикладних розробок із названої проблеми, їхня практична значущість визначили вибір теми дослідження.

Мета статті - проаналізувати рівень інноваційності та результати ін-новаційної діяльності Україні, запропонувати шляхи підвищення рівня інноваційної активності в сучасних умовах зовнішніх викликів. Методи дослідження включають положення теорії ефективності суспільного виробництва, економічного аналізу, порівняння, статистичні методи.

Виклад основного матеріалу. Питання підвищення рівня конкурентоспроможності галузей національного господарства держав через розвиток інноваційної діяльності в умовах глобального економічного співтовариства знаходяться завжди у центрі уваги. Сучасні країни світу досить диференційовані за рівнем інноваційності та результатами інноваційної діяльності. Лідером рейтингу найбільш інноваційних країн світу, за версією Bloomberg 2020 року, стала Німеччина, подолавши шестирічну серію перемог Південної Кореї. Загальновідомо, що індекс інноваційного розвитку агентства Bloomberg (Bloomberg Innovation Index) оцінює інноваційність економік на підставі низки критеріїв, таких як: витрати на НДДКР щодо ВВП, продуктивність, відсоток інноваційних компаній у загальній кількості підприємств, кількість науковців на мільйон жителів, додана вартість виробництва щодо ВВП, відсоток випускників ЗВО у загальній кількості випускників освітніх установ і патентна активність. До переліку країн-лідерів багато років за рівнем інноваційності стабільно входили: США, Швеція, Об'єднане Королівство, Сінгапур, Швейцарія, Данія, Нідерланди. За даними останнього оприлюдненого звіту, США опустилися на одну сходинку, до 9 місця. Однак США є лідером за двома показниками: проникнення високих технологій (частка інноваційних компаній в загальній кількості підприємств) та патентна активність. Так, се-ред 20 біржових компаній із найвищими витратами на дослідження і розробки в останні фінансові роки половина була зі США, на чолі $з$ Amazon.com Inc., Alphabet Inc. i Microsoft Corp. Німеччина посіла друге місце з чотирма: Volkswagen AG, Daimler AG, Siemens AG i Bayer AG. У п'ятірку лідерів загального рейтингу увійшли Швейцарія, Швеція та Сінгапур, на чотири сходинки втратила позиції Фінляндія і посіла сьоме місце у цьому рейтингу. У 2019 р. Україна посіла 53-е місце в рейтингу iз загальним балом 48,09 (роком раніше Україна займала 46-у сходинку рейтингу). Таке падіння зумовлено послабленням позиції України за 6 із 7 складників цього індексу (табл. 1). В Інноваційному індексі Bloomberg 2020 року Україна посіла 56-е місце в рейтингу із загальним балом 48,24. Варто зазначити, що у 2019 році в рейтингу з'явилося 10 нових країн, чотири 3 яких (Словенія, Бразилія, Об'єднані Арабські Емірати і Аргентина) розташувалися в рейтингу вище за Україну і фактично витіснили її за межі ТОП-50. За 
Таблиця 1 - Місце України за складниками Інноваційного індексу Bloomberg у 2018-2020 рр.

\begin{tabular}{|c|c|c|c|c|c|c|c|c|}
\hline & 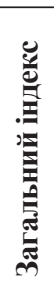 & 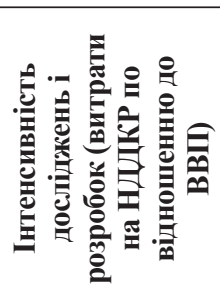 & 总 & 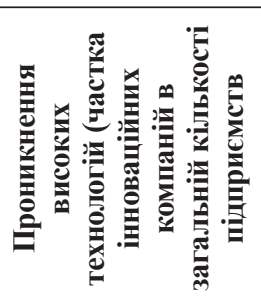 & 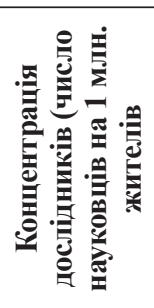 & 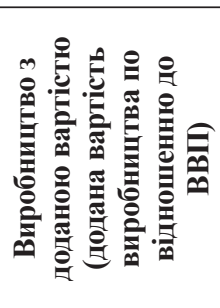 & 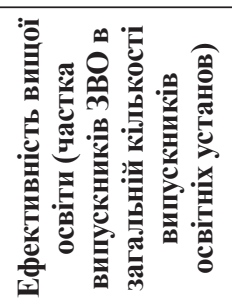 & 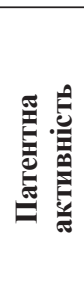 \\
\hline 2018 & 46 & 47 & 50 & 32 & 46 & 48 & 21 & 27 \\
\hline 2019 & 53 & 54 & 60 & 37 & 46 & 58 & 28 & 35 \\
\hline 2020 & 56 & 57 & 57 & 57 & 35 & 48 & 49 & 36 \\
\hline
\end{tabular}

Джерело: [9, с. 2; 11, с. 9]

версією Bloomberg-2020, дебютантами стали Сгипет (46,29 балів) та Казахстан (46,10 балів) [9].

Результати досліджень свідчать про дуже скромні зусилля України у сфері інновацій та підтверджують відому аксіому - неможливо утримати до-сягнуті позиції в конкурентній боротьбі без цілеспрямованих, системних дій держави, заснованих на принципах державно-приватного партнерства у фі-нансуванні інноваційних проектів.

Слід відзначити, що показники витрат на дослідження i розробки, до-даної вартості реального сектору економіки (наприклад, обробної промисловості), продуктивності, концентрації високотехнологічних компаній, реєстрації патентів і кількості дослідників виявилися настільки слабкими, що не дозволили економіці утримати позиції в рейтингу. Майже десять років поспіль в Україні частка неінноваційних підприємств становить близько $80 \%$. Через відсутність ефективної державної політики розкіш інноваційної діяльності можуть собі дозволити в основному великі підприємства, причому за рахунок власних коштів. У загальному обсязі інноваційних витрат майже 70\% йде на придбання машин, обладнання та програмного забезпечення, 15\% - на виконання внутрішніх НДДКР, лише 9,1\% -на фінансування зовнішніх досліджень. Таким чином, низька здатність до інновацій України зумовлена тим, що підприємства освоюють нові технології, переважно імпортуючи інвестиційні товари, а не докладаючи зусиль до створення (удосконалення) нових продуктів і процесів. За статистикою, в загальних витратах підприємницького сектора на НДДКР 90,9\% витрат пов'язано 3 науково-технічними (експериментальними) розробками, тоді як установи вищої освіти присвячу-ють цьому лише 1,8\% фінансування [10].

Щоби зрозуміти причини ситуації, що склалася, i проблеми, що стоять в інноваційній сфері, необхідно розглянути значення національної інноваційної системи та іiі роль у прискоренні наукових досліджень розробок, перш за все в промисловому виробництві. С досить багато визначень національної інноваційної системи. Для цілей дослідження достатньо досить простого й інтуїтивно зрозумілого визначення національної інноваційної системи як системи, в якій кожна складова частина і їх зв'язки одна з одною створюють складну мережу симбіотичних взаємодій (людей, організацій, ресурсів і структур), які в сукупності перетворюють знання в нові технології, продукти і послуги, що споживаються на національних або глобальних ринках, і навіть спосіб життя.

Визначальну роль у функціонуванні національної інноваційної системи відіграє держава, яка визначає правила функціонування і взаємодії учасників інноваційного процесу через формування нормативно-правового середовища. Сьогодні реальні дії органів влади часто прямо протилежні інноваційно орієнтованій державній політиці соціально-економічного розвитку країни. У підсумку за час незалежності України: в 3,3 раза знизилася чисельність працівників в інноваційній сфері (у Західній Свропі зросла в 2 рази, у Південно-Східній Азії - в 4 рази); в 7 разів впала (з 56\% до 11\%) частка інноваційно-активних промислових підприємств (у Росії їхня частка становить 10\%, у Польщі - 16\%, у СС - у середньому 60\%); приріст ВВП за рахунок впровадження нових технологій в Україні становить $0,7 \%$, тоді як у розвинених країнах цей показник досягає 60-90\%» [12, с. 60]. Аналогічне становище спостерігається і сьогодні. 3 року в рік скорочується кількість промислових підприємств, що займаються інноваційною діяльністю. Скоротилася частка промислових підприємств, що впроваджували інновації (продукцію та/або технологічні процеси), в загальній кількості промислових підприємств. Якщо в 2016 р по Україні частка таких підприємств становила 16,6\%, то в 2017 p - 14,3\%, в 2018 р - тільки 15,6\%, в 2019 г. $13,8 \%$. Стійка тенденція до зниження спо-стерігається за показником кількості співробітників наукових організацій, що задіяні у виконанні наукових досліджень та науково-технічних робіт. Так, статистичні дані свідчать, що в 2016 році цей показник склав 97912 осіб, у 2017 році - 94274 осіб, у 2018 році - 88128 осіб, у 2019 році - 79262 осіб [13]. На наукові дослідження в Україні, згідно з Ranking Countriess Impact on Global Innovation, виділяють всього $\$ 90$ на людину, тоді як в Ізраїлі - \$ 1990, в США - \$ 1471, в Естонії - \$ 1303.

Оскільки існуюча в Україні національна інноваційна система i норма-тивно-правове поле функціонування iі елементів сьогодні не утворюють єдину конструкцію, результати інноваційної діяльності не проявляються у вигляді збільшення виробництва високотехнологічних товарів і посилення конкурентоспроможності економіки.

Практика свідчить, що практичне втілення новацій відбувається безпосередньо за допомогою власників бізнесу та управлінців (таблиця 2), чому сприяє застосування відповідних ефективних механізмів із реаліза- 
Таблиця 2 - Топ найбільш інноваційних компаній України

\begin{tabular}{|c|c|c|c|}
\hline Компанія & Інновації & Галузь & $\begin{array}{l}\text { Локалізація } \\
\text { підприсмств }\end{array}$ \\
\hline $\begin{array}{l}\text { «Астарта» - вертикально інтегрований } \\
\text { холдинг у сфері цукрового і } \\
\text { сільськогосподарського виробництва. }\end{array}$ & $\begin{array}{l}\text { Корпоративна інформаційно- } \\
\text { аналітична платформа управління } \\
\text { аграрним бізнесом }\end{array}$ & $\begin{array}{l}\text { Рослинництво, } \\
\text { тваринництво, } \\
\text { виробництво цукру, } \\
\text { переробка сої }\end{array}$ & $\begin{array}{l}\text { Полтавська, } \\
\text { Вінницька, } \\
\text { Хмельницька та } \\
\text { інші області }\end{array}$ \\
\hline $\begin{array}{l}\text { Автомобільна компанія «Богдан Моторс» - } \\
\text { головний виробничий актив корпорації } \\
\text { «Богдан». }\end{array}$ & $\begin{array}{l}\text { Екологічна модернізація } \\
\text { Луцького автоскладального } \\
\text { заводу, розробка бронеавтомобіля } \\
\text { «Барс-8» на Черкаському } \\
\text { автоскладальному заводі } \\
\end{array}$ & Автомобілебудування & $\begin{array}{l}\text { Черкаси, Луцьк } \\
\text { та ін. }\end{array}$ \\
\hline $\begin{array}{l}\text { ДТЕК ВДЕ ( DTEK Renewables) виробляє } \\
\text { електроенергію на вітрових і сонячних } \\
\text { електростанціях. Компанія управляє двома } \\
\text { ВЕС і двома СЕС загальною потужністю } \\
510 \text { МВт, що становить 15\% ринку } \\
\text { потужностей ВДЕ України. }\end{array}$ & $\begin{array}{l}\text { Перша в Україні діджітальна } \\
\text { підстанція на Приморській } \\
\text { ВЕС, мегамасштабная АСУТП } \\
\text { на Нікопольської СЕС, система } \\
\text { моніторингу стану турбін на } \\
\text { Ботієвській ВЕС }\end{array}$ & «Зелена» енергетика & $\begin{array}{l}\text { Запорізька, } \\
\text { Херсонська, } \\
\text { Дніпропетровська } \\
\text { області }\end{array}$ \\
\hline $\begin{array}{l}\text { «Інтергал-Буд» будівельна компанія, яка } \\
\text { реалізує комфортні та сучасні житлові } \\
\text { проекти в Києві і ряді інших міст України. } \\
\text { Тримаючи руку на пульсі змін, компанія } \\
\text { зосереджена на впровадженні інновацій. }\end{array}$ & $\begin{array}{l}\text { Футуристична архітектура } \\
\text { багатофункціонального } \\
\text { житлового комплексу Intergal City } \\
\text { i iн. }\end{array}$ & Будівництво & $\begin{array}{l}\text { Київ, Львів, } \\
\text { Рівне, Чернівці, } \\
\text { Житомир, } \\
\text { Ужгород, } \\
\text { Мукачево }\end{array}$ \\
\hline $\begin{array}{l}\text { «Кліар Енерджі» займається будівництвом } \\
\text { і експлуатацією електростанцій на біомасі, } \\
\text { біогазі, вітрі і сонячної енергії. }\end{array}$ & $\begin{array}{l}\text { Будівництво та експлуатація } \\
\text { біотеплоелектростанцій, } \\
\text { біогазових установок, сонячних і } \\
\text { вітрових електростанцій }\end{array}$ & «Зелена» енергетика & $\begin{array}{l}\text { Корюківська ТЕС } \\
\text { та інші об'єкти } \\
\text { в } 10 \text { областях } \\
\text { України }\end{array}$ \\
\hline $\begin{array}{l}\text { LimpidArmor Inc. - український } \\
\text { технологічний стартап, що спеціалізується } \\
\text { на віртуальній і доповненої реальності } \\
\text { (VR \& AR), робототехніці, штучному } \\
\text { інтелекті та аналізі даних. Є офіційним } \\
\text { партнером Microsoft, Optix i Nvidia. }\end{array}$ & $\begin{array}{l}\text { Система Land Platform } \\
\text { Modernization Kit для важкої } \\
\text { броньованої техніки }\end{array}$ & IT-розробки & Київ \\
\hline $\begin{array}{l}\text { «Октава Кіберзахіст» - перший в Україні } \\
\text { оператор послуг з кіберзахисту. Компанія } \\
\text { заснована в } 2017 \text { році як реакція на } \\
\text { вразливість українського бізнесу і } \\
\text { держсектору перед кібератаками. }\end{array}$ & $\begin{array}{l}\text { Створення Центру управління } \\
\text { кібербезпекою }\end{array}$ & IT-послуги & Київ \\
\hline $\begin{array}{l}\text { Olymp Alcohol Company - Лікеро- } \\
\text { горілчаний завод PRIME (виробничий } \\
\text { майданчик OLYMP Alcohol Сотрапу), } \\
\text { побудований з нуля, почав свою роботу в } \\
2006 \text { р. Інноваційне, сучасне підприємство } \\
\text { здатне виробляти } 24 \text { млн бут. / міс. Вперше } \\
\text { в Україні на заводі РRIME відкрито } \\
\text { виробництво першої крафтової горілки } \\
\text { на основі авторських рецептів відомого } \\
\text { ботаніка Клима Житника. }\end{array}$ & $\begin{array}{l}\text { Крафтовий цех для виробництва } \\
\text { першої крафтової горілки в } \\
\text { Україні }\end{array}$ & $\begin{array}{l}\text { Виробництво } \\
\text { алкогольних напоїв }\end{array}$ & $\begin{array}{l}\text { смт. Малинівка, } \\
\text { Харківська } \\
\text { область }\end{array}$ \\
\hline $\begin{array}{l}\text { ПАТ «САН ІнБев Україна» (АВ InBev } \\
\text { Efes) є одним з лідерів українського } \\
\text { пивоварного ринку. Це спільне } \\
\text { підприємство найбільшої в світі } \\
\text { пивоварної компанії АВ InBev (Anheuser- } \\
\text { Busch InBev) і найбільшої пивоварної } \\
\text { компанї̈ Туреччини Anadolu Efes. }\end{array}$ & $\begin{array}{l}\text { Запуск програми 100+ Accelerator } \\
\text { для підтримки підприємців, які } \\
\text { вирішують глобальні проблеми } \\
\text { сталого розвитку }\end{array}$ & Виробництво пива & $\begin{array}{l}\text { Пивоварні в } \\
\text { Чернігові, Харкові } \\
\text { та Миколаєві }\end{array}$ \\
\hline $\begin{array}{l}\text { «Укрлендфармінг» - найбільший } \\
\text { український агропромисловий холдинг за } \\
\text { обсягом земельного банку і виробництвом } \\
\text { яєць. Група компаній вирощує } \\
\text { сільськогосподарські культури, розводить } \\
\text { велику рогату худобу для виробництва } \\
\text { молока і м'яса. Яйця і яєчні продукти група } \\
\text { експортує в } 40 \text { країн світу. }\end{array}$ & $\begin{array}{l}\text { Виробництво яєчного порошку, } \\
\text { «мармурової» яловичини і ін. }\end{array}$ & $\begin{array}{l}\text { Рослинництво, } \\
\text { тваринництво, } \\
\text { виробництво } \\
\text { яєць і яєчних } \\
\text { продуктів, харчова } \\
\text { промисловість }\end{array}$ & $\begin{array}{l}\text { Всеукраїнська } \\
\text { мережа } \\
\text { агропромислових } \\
\text { активів }\end{array}$ \\
\hline
\end{tabular}

Джерело: [14] 
ції інноваційних розробок у життя. Головні стратегічні завдання інноваційних компаній України полягають у забезпеченні ефективного розвитку науково-технічного, інноваційного та економічного потенціалів підприємства, довгострокової конкурентоспроможності, стабільного фінансового стану. Найважливішими передумовами вирішення поставлених завдань були: розроблення та впровадження корпоративної комплексної системи управління конкурентоспроможністю; принципово новий, який концептуально відрізняється від традиційного, підхід до оцінки рівня конкурентоспроможності підприємства; вибір і реалізація сучасної конкурентної стратегії ринку, продукту і технології.

Як випливає 3 визначення національної інноваційної системи, основ-ним результатом її функціонування $\epsilon$ збільшення обсягів виробництва нау-комісткої продукції. Досягнення практично всіх цілей Уряду (зростання ВВП, підвищення якості життя населення, підвищення рівня конкурентосп-роможності і т.д.) зводяться в кінцевому підсумку до того, наскільки ефективно буде організовано виробництво за умов отримання i збереження конкурентних переваг.

Визнаний авторитет у галузі проблем конкуренції М. Портер, чиї ви-сновки базуються на результатах великомасштабного дослідження процесів отримання і збереження конкурентної переваги, вважає, що фірми обходять своїх суперників, якщо мають міцну конкурентну перевагу.

Конкурентна перевага поділяється на два основних види: більш низькі витрати і диференціація товару. Низькі витрати відбивають здатність фірми розробляти, випускати і продавати порівнянний товар 3 меншими витратами, ніж конкуренти [15, с. 49-60]. Це означає, що передумови для забезпечення низьких витрат повинні створюватися на всіх стадіях виробничого циклу, в тому числі на стадіях НДР і ДКР. Для того щоб займатися науково-виробничою діяльністю, сучасні підприємства повинні володіти стандартним набором основних ресурсів. Від наявності та стану цих ресурсів, від можливостей підприємств їх використовувати залежить ефективність інноваційної діяльності, тому коротко охарактеризуємо деякі ресурси з погляду можливих конкурентних переваг інноваційних підприємств України.

Певні недоліки полягають насамперед у недостатньому фінансуванні. Слід зазначити, що НДР і ДКР де-юре підтримуються державою, законодавством встановлено, що на науку щороку повинно виділятися щонайменше 1,17\% від ВВП. За аналізований 2018-2019 рр. обсяг фінансування становив лише 0,17\% від ВВП. Це у багато разів менше, аніж у розвинутих країнах (від 1,7 \% у Канаді до 4,7\% у Південній Кореї). Основним джерелом фінансування інноваційних витрат залишаються власні кошти підприємств у цілому по промисловості та у розрізі всіх технологічних секторів - від 72,6\% до 97,3\% у 2017 році (власні кошти підприємств у \% до загального обсягу витрат на інновації у 2018 році склали $88,2 \%$, у 2019 році $-87,7 \%$ ).

Нині науково-дослідницька база дослідних організацій в основному застаріла. Виробничі потужності промислових підприємств машинобудівного комплексу також в основному застаріли. Верстатний парк старіє і змінюється в бік використання найпростіших універсальних верстатів. Наприклад, продукція заводів ПАТ «Турбоатом» та ГП «Електроважмаш» (м. Харків) має нині замовлення у далекому зарубіжжі, що забезпечує їм нормальне фінансово-економічне становище. Однак вони постачають продукцію, розроблену ще у 60-80-х роках минулого сторіччя, яка нині застаріла. Її переважно застосовують для потреб ремонту і заміни обладнання в існуючих комплексах. Матеріально-технічна база проектно-дослідницьких організацій та суб'єктів підприємництва також не відповідає сьогоднішнім вимогам. Це $є$ однією з причин того, що більшість видів вітчизняної промислової продукції належить до 2-4 технологічних укладів, водночас як у розвинутих країнах - до 5-6 укладів і частково до 4-го [16, с. 30-31]. Невиправдано низьку частку вітчизняних підприємств на світовому ринку пояснює низький рівень розвитку системи збуту наукоємної продукції.

Загалом можна зробити висновок, що інноваційна активність підпри-ємств, яка в сучасних умовах є одним 3 головних факторів підвищення їхньої конкурентоспроможності, а отже, й ефективності функціонування, поки недостатня. Але, незважаючи на незначні масштаби інноваційної діяльності та карантинний форсмажор, який вніс серйозні зміни в договірні відносини між партнерами, її позитивний вплив, як показує практика, безперечний. Більшість підприємств, що впроваджували інновації, отримали приріст продукції, підвищили іiі конкурентоспроможність, розширили ринки збуту. Досвід Новокраматорського машинобудівного заводу (НКМЗ) дає вагомі підстави для такого висновку. Сьогодні НКМЗ - це найбільше в Європі підприємство індивідуального важкого машинобудування, яке стійко працює та є прибутковим акціонерним товариством (завод в умовах карантинного форс-мажору відвантажив замовнику - компанії «Енергостіл», м. Київ, інноваційний шаропрокатний стан ШПС 60-100). Для підтримки конкурентної переваги інноваційна й інвестиційна політика на заводі формується з урахуванням світових тенденцій, вимог та строго підпорядкована вирішенню конкретних проблем.

Таким чином, проведений аналіз результатів інноваційного розвитку дозволяє зробити висновок, що виробничий, науковий і інноваційний потенціал загалом по Україні діє, але потрібні додаткові заходи 3 його активізації. У цьому плані перед вітчизняними підприємствами в умовах завершення пандемії, спричиненої поширенням коронавірусу COVID-19, постають серйозні завдання щодо подальшого поліпшення свого потенціалу, забезпечення його трансформації в чинники успіху, які і повинні визначити умови, необхідні для реалізації їхньої соціально-орієнтованої стратегії розвитку.

Висновки. На підставі вищевикладених фактів можна зробити висно-вок, що окремі конкурентні переваги інноваційної системи України не підкріплені комплексом ресурсів і з часом втрачають своє значення, а карантин-ний форс-мажор спровокує і без того наявний дефіцит фінансових ресурсів в бюджеті України. Вирішення існуючих проблем, на наш погляд, можливе шляхом розвитку структурних елементів інноваційної інфраструктури, які довели свою ефективність у країнах ЄС: кластерів та технологіч- 
них плат-форм, особливо останніх, як механізму державно-приватного партнерства в інноваційній сфері. Саме інноваційна інфраструктура багато в чому визначає перспективи інноваційної діяльності підприємств реального сектору еконо-міки. Проте слід відразу зазначити, що об'єкти інноваційної інфраструктури можуть вирішувати лише частину проблем, і успіш- ний розвиток інноваційної діяльності не може бути поставлено виключно в залежність від наявності або кількості відповідних об'єктів інфраструктури. Національна інноваційна система для успішного функціонування повинна мати також сприятливу нормативно-правову базу та ефективну систему виведення на ринки продукції інноваційних підприємств.

\section{Список використанних джерел:}

1. Крамар О. Невиправданий оптимізм : веб-сайт. URL: https:/tyzhden.ua/Economics/244319 (дата звернення 14.06.2020).

2. Бакуменко В.Д. Формування державно-управлінських рішень: проблеми теорії, методології, практики. Київ, 2000.325 с.

3. Активізація інноваційної діяльності: організаційно-правове та соціально-економічне забезпечення : монографія / О. І. Амоша та ін. Донецьк : IЕП НАН України, 2007. 328 с.

4. Андрощук Г.О., Давимука С.А, Федулова Л.І. Національні інноваційні системи: еволюція, детермінанти результативності : монографія. Київ : Парламентське видавництво, 2015. 512 с.

5. Інноваційна Україна 2020 : національна доповідь / за ред. В.М. Гейця. Київ : НАН України, 2015. 336 с.

6. Інноваційний розвиток регіонів України / О. П. Коюда та ін. ; за ред. В. С. Пономаренка. Харків : IНЖЕК, 2014. 363 с.

7. Харченко О.С. Організаційно-економічний механізм розвитку національної інноваційної системи: дис. ... канд. екон. Наук : 08.00.03. Маріуполь, 2015. 201 с. URL: http://www.dgma.donetsk.ua/docs/nauka/vcheni_rady/12.105.03/21diser.pdf (дата звернення 27.05.2020).

8. Федулова Л.І., Марченко О.С. Інноваційні екосистеми: сутність та методологічні засади формування. Економічна теорія та право. 2015. № 2(21). C. 21-33. URL: http://econtlaw.nlu.edu.ua/wpcontent/uploads/2015/11/2_21.pdf (дата звернення 03.06.2020).

9. Bloomberg Innovation Index (2020) : веб-сайт. URL: https://www.bloomberg.com/news/articles/2020-01-18/germany-breakskorea-s-six-year-streak-as-most-innovative-nation (дата звернення 01.03.2020).

10. Гиршфельд A. Zeitgeist инноваций : веб-сайт. URL: https://lb.ua/economics/2018/06/08/399832 zeitgeist innovatsiy.html (дата звернення 12.06.2020).

11. Стан інноваційної діяльності та діяльності у сфері трансферу технологій в Україні у 2018 році: аналітична довідка / Т.В. Писаренко та ін. Київ : УкрIHTEI, 2019. 80 с. URL: https://mon.gov.ua/storage/app/media/innovatsii-transfertehnologiy/2019/07/03/stan-innov-diyaln-2018f.pdf (дата звернення 27.02.2020).

12. Мазур А.А., Пустовойт С.В. Технологічні парки України: цифри, факти, проблеми. Наука та інновації. 2013. № 3. T. 9. C. 59-72. URL: http://dspace.nbuv.gov.ua/xmlui/bitstream/handle/123456789/114314/08-Mazur.pdf?sequence=1 (дата звернення 27.02.2020).

13. Державна служба статистики. Економічна статистика: Наука, технології та інновації : веб-сайт. URL: www.ukrstat.gov.ua (дата звернення 07.06.2020).

14. Вишневский Ю. ТОП-20 самых инновационных компаний Украины : веб-сайт. URL: https://www.dsnews.ua/vlast_deneg/ top-20-samyh-innovatsionnyh-kompaniy-ukrainy-30112018230000 (дата звернення 27.02.2020).

15. Портер М. Конкуренция: учебное пособие / за ред. Я.В. Заблоцкого. Москва : Издательский дом «Вильямс», 2000.495 с.

16. Яковлев А.І. Аналіз стану інноваційної діяльності в Україні та шляхи його поліпшення. Наука та наукознавство. 2018. № 2 (100). C. 29-44. URL: http://dspace.nbuv.gov.ua/handle/123456789/142115 (дата звернення 01.03.2020).

17. Про схвалення Стратегії розвитку сфери інноваційної діяльності на період до 2030 року» : Розпорядження Кабінету міністрів України від 10 липня 2019 р. № 526-p / Верховна Рада України. URL: https://www.kmu.gov.ua/npas/pro-shvalennyastrategiyi-rozvitku-sferi-innovacijnoyi-diyalnosti-na-period-do-2030-roku (дата звернення 12.06.2020)

\section{References:}

1. Kramar O. (2020). Nevypravdanyi optymizm [Unjustified optimism]. Available at: https://tyzhden.ua/Economics/244319. [in Ukrainian]. (accessed 14 June 2020)

2. Bakumenko V.D. (2000). Formuvannia derzhavno-upravlinskykh rishen: problemy teorii, metodolohii, praktyky [The formation of public management decisions: problems of theory, methodology, practice]. Kyev: UADU. [in Ukrainian].

3. Amosha O.I., Antonyuk V.P., Zemlyankin A.I. etc. (2007). Aktyvizatsiia innovatsiinoi diialnosti: orhanizatsiino-pravove ta sotsialno-ekonomichne zabezpechennia [Activation of innovative activity: organizational and legal and socio-economic support]. Donetsk: NAN Ukrainy, Instituted ekonomiki promislovosti. 328 p. [in Ukrainian].

4. Androshchuk H.O., Davymuka S.A, Fedulova L.I. (2015). Natsionalni innovatsiini systemy: evoliutsiia, determinanty rezultatyvnosti [National Innovation Systems: Evolution, Determinants of Effectiveness]. Kyiv: Parlamentske vydavnytstvo Publ. 512 p. [in Ukrainian].

5. Geitsa V.M., Danilenko A.I., Libanova E.M., Gritsenko A.A, etc. (2015). Innovatsiina Ukraina 2020: natsionalna dopovid [Innovative Ukraine 2020: national report]. Kyiv: NAN Ukrainy. 336 p. [in Ukrainian].

6. Koiuda O. P. et al. (2014). Innovatsiinyi rozvytok rehioniv Ukrainy [Innovative development of regions of Ukraine]. Kharkiv: VD «INZhEK». 363 p. [in Ukrainian].

7. Kharchenko O.S. (2015). Orhanizatsiyno-ekonomichnyy mekhanizm rozvytku natsional'noyi innovatsiynoyi sys temy [Organizational and economic mechanism for the development of the national innovation system] PhD (Ekonom.). Mariupol: Priazov State Technical University. Available at: http://www.dgma.donetsk.ua/docs/nauka/vcheni_rady/12.105.03/21diser.pdf. [in Ukrainian]. (accessed 27 May 2020)

8. Fedulova L.I., Marchenko O.S. (2015). Innovatsiini ekosystemy: sutnist ta metodolohichni zasady formuvannia. [Innovative ecosystems: essence and methodological bases of formation.] Ekonomichna teoriia ta pravo. № 2(21). pp. 21-33. Available at: http://econtlaw.nlu.edu.ua/wpcontent/uploads/2015/11/2_21.pdf. [in Ukrainian]. (accessed 3 June 2020).

9. Bloomberg Innovation Index (2020). Available at: https://www.bloomberg.com/news/articles/2020-01-18/germany-breakskorea-s-six-year-streak-as-most-innovative-nation (accessed 1 March 2020). 
10. Girshfel'd A. (2018). Zeitgeist innovacij [Zeitgeist Innovation] Available at: https://b.ua/economics/2018/06/08/399832 zeitgeist innovatsiy.html. [in Russian]. (accessed 12 June 2020)

11. Py`sarenko T.V., et all. (2019). Stan innovatsiinoi diialnosti ta diialnosti u sferi transferu tekhnolohii v Ukraini u 2018 rotsi: analitychna dovidka [The state of innovation and activity in the field of technology transfer in Ukraine in 2018: analytical reference]. Available at: https: //mon.gov.ua/storage/app/media/innovatsii-transfer-tehnologiy/2019/07/03/stan-innov-diyaln-2018f. pdf. [in Ukrainian]. (accessed 27 February 2020)

12. Mazur A.A., Pustovoit S.V. (2013). Tekhnolohichni parky Ukrainy: tsyfry, fakty, problemy [Technological parks of Ukraine: figures, facts, problems]. Nauka ta innovatsii. № 3. T. 9. pp. 59-72. Available at: http://dspace.nbuv.gov.ua/xmlui/bitstream/ handle/123456789/114314/08-Mazur.pdf?sequence=1. [in Ukrainian]. (accessed 27 February 2020)

13. Derzhavna sluzhba statystyky Ukrainy (2020). Ekonomichna statystyka: Nauka, tekhnolohii ta innovatsii [Economic statistics: Science, technology and innovation]. Available at: www.ukrstat. gov.ua [in Ukrainian]. (accessed 7 June 2020).

14. Vishnevskij YU. (2018). TOP-20 samyh innovacionnyh kompanij Ukrainy [TOP-20 of the most innovative companies in Ukraine]. Available at: https://www.dsnews.ua/vlast deneg/top-20-samyh-innovatsionnyh-kompaniy-ukrainy-30112018230000. [in Russian]. (accessed 27 February 2020)

15. Porter M. (2000). Konkurenciya [Competition]. Moskva: Izdatel'skij dom «Vil'yams». [in Russian].

16. Yakovlev A.I. (2018) Analiz stanu innovatsiinoi diialnosti v Ukraini ta shliakhy yoho polipshennia [Analysis of innovation in Ukraine and ways to improve it]. Nauka ta naukoznavstvo № 2 (100). pp. 29-44. Available at: http://dspace.nbuv.gov.ua/ handle/123456789/142115. [in Ukrainian]. (accessed 1 March 2020)

17. Pro skhvalennia Stratehii rozvytku sfery innovatsiinoi diialnosti na period do 2030 roku. (2019). [On approval of the Strategy for the development of the sphere of innovative activity for the period until 2030]: Rozporiadzhennia Kabinetu ministriv Ukrainy vid 10 lypnia 2019 r. № 526-r / Verkhovna Rada Ukrainy. [in Ukrainian]. Available at: https://www.kmu.gov.ua/npas/pro-shvalennyastrategiyi-rozvitku-sferi-innovacijnoyi-diyalnosti-na-period-do-2030-roku [in Ukrainian]. (accessed 12 June 2020)

Vecepura Natalia

Kyiv National University of Culture and Arts

\section{INNOVATIVE SYSTEM OF UKRAINE UNDER CONDITIONS OF GLOBALIZATION PROCESSES: STATE AND PROSPECTS FOR DEVELOPMENT}

The article presents the results of a study of the state and prospects of development of the innovative system of Ukraine in modern conditions. The author has proved that modern countries of the world are quite differentiated by the level of innovation and the results of innovation. In the Bloomberg Innovation Index 2020, Ukraine ranked 56th in the ranking with a total score of 48.24. The key structural problem of the national economy, which impedes its further development, is the weak innovative potential of industry, which determines the weak competitive position of a number of key industries in the world market. The system of reproduction and consumption of innovations has been destroyed, and the remaining centers of competencies are not able to independently provide the entire economy with new technological solutions. It is noted that the low activity of Ukrainian industrial enterprises in the field of creation and implementation of innovations does not allow the country to approach the leaders of innovative development. The reasons that led to the stagnation of the innovative development model of our country are highlighted: low technological level of production, low innovative activity of enterprises in the real sector of the economy, poor state financing of innovative developments, lack of own funds for innovative activities. The problem of enhancing innovation in the domestic economy is gaining importance in the context of the program of reviving the Ukrainian economy and improving the overall management efficiency. The disparate elements of the national innovation system and the legal framework for their functioning today in Ukraine do not form a single block, in this regard, among the priority tasks is the development of the architecture of the innovation ecosystem, as well as the creation of a full-fledged legislative and regulatory environment that stimulates innovation processes. Central to the study of this issue is the development of innovative infrastructure. It is the developed innovation infrastructure that is the environment that allows, as soon as possible, systematically searching for and developing innovative technologies.

Key words: competitiveness, innovation, national innovation system, strategic objective, competitive advantage, efficiency, innovation infrastructure.

JEL classification: M21, O14, O31 